\title{
Sciendo
}

Administration, vol. 67, no. 3 (2019), pp. 7-39

doi: 10.2478/admin-2019-0019

\section{Visions and plans for regional development in Ireland}

\author{
James A. Walsh \\ Department of Geography and Social Sciences Institute, \\ Maynooth University, Ireland
}

\begin{abstract}
The evolution of spatial planning in Ireland, and more widely, has been a complex process in which many narratives have been explored at different times. In 2018 the government published the National Planning Framework (NPF) to guide and support the achievement of a challenging and potentially transformative development strategy for Ireland 2040. The NPF is grounded in a vision that sets out to be disruptive of what has become embedded as the status quo in political, administrative and planning decision-making. While it is a very innovative addition to the portfolio of government policies and strategies, it is not the first time that radical visions have been proposed. This paper reviews previous visions and plans for regional development that have been proposed over the last seventy-five years, and critically compares and contrasts the approaches represented by the National Spatial Strategy (200220) and the NPF (2018-40), including the subsequent draft regional spatial and economic strategies. The implications of the population projections and the proposed settlement patterns for the achievement of the NPF objective of effective regional development, which is expressed as a regional parity target, are closely examined.
\end{abstract}

Keywords: De Valera vision for Ireland, Gibney Irish National Plan, National Spatial Strategy, National Planning Framework, regional demographic projections and settlement proposals 


\section{Visions and plans for regional development in Ireland}

In spring 2018 the government of Ireland published the National Planning Framework (NPF) to guide and support the achievement of a challenging and potentially transformative comprehensive development strategy for Ireland 2040. The NPF is a long-term framework that sets out how Ireland can move away from the current 'business as usual' pattern of development by disrupting trends that have been apparent for the last fifty years and have accelerated over the past twenty. The purpose of the NPF is 'to enable all parts of Ireland, whether rural or urban, to successfully accommodate growth and change, by facilitating a shift towards Ireland's regions and cities other than Dublin, while also recognising the ongoing key role of the capital city' (Government of Ireland, 2018, p. 20). The NPF is therefore grounded in a vision that sets out to be disruptive of what has become embedded as the status quo in political, administrative and planning decision-making in both the public and private sectors. It is not the first time that radical visions have been proposed. The purpose of this paper is to review and reflect on previous visions and plans for regional development that have been proposed over the last seventyfive years, and to critically compare and contrast the approaches represented by the National Spatial Strategy (NSS) (Government of Ireland, 2002) and the NPF, including the subsequent draft regional spatial and economic strategies (RSESs).

The evolution of spatial planning in Ireland, and more widely, has been a complex process in which many narratives have been explored at different times. They include (a) the concept of region where administrative, theoretical and politically pragmatic proposals have been proposed and contested; (b) the objective of development as more efficient economic growth versus a multidimensional, pluralistic and intergenerational approach to sustainability for the economy, society and environment; (c) the appropriate scale for objectives convergence of Ireland as a region towards the EU average or reduction of interregional disparities in Ireland; (d) the choice of performance metrics; (e) the challenges and opportunities for cities, towns and rural areas; the role of professional planners and the legitimacy of planning decisions; (f) the types of knowledge and evidence used to reach, or to inform, strategic decisions; and (g) the scope for participation by diverse stakeholders in the design, implementation and governance of strategic spatial plans. The experience in Ireland (Bartley, 2007) reflects the paradigm shifts in 
planning from technical rationality to strategic communicative rationality that have occurred elsewhere over recent decades (Albrechts, 2001; Albrechts et al., 2017; Allmendinger, 2009; Davoudi, 2012; Davoudi \& Strange, 2009; Faludi, 2000, 2003; Healy, 1998, 2006; Walsh, 2019).

\section{Pioneers in national planning - Early visions}

The harsh economic and social conditions that prevailed in Ireland in the 'Emergency' years of the early 1940s provided an unexpected opportunity for reflection by some architects, engineers and others on the preparation of a National Plan for Ireland. The first National Planning Conference was organised in 1943 by Manning Robertson, the father of town planning in Ireland (Bannon, 1989; MacCabe, 2018; O'Leary, 2014). A key objective of the conference was to educate the public on the necessity and importance of national planning and convince the government that there was broad-based support for planning. However, from the outset there was evidence of scepticism among political leaders of the ideals espoused by the professionals. For instance, the government advised that the president of the country should not be associated with the opening of the conference and the Taoiseach, Éamon de Valera, expressed his personal opinion that 'planning is a very interesting but a very seductive occupation. It can very easily become little more than daydreaming or building castles in the air' (quoted in MacCabe, 2018, p. 33).

Despite the absence of any tangible political support for a professional approach to planning, a highly original document was prepared in 1943 in a personal capacity by the architect and town planner Frank Gibney. His Framework for an Irish National Plan (Gibney, 1943a) was published to coincide with the National Planning Conference. His aim was to arouse public interest in planning and to assist in 'discerning what people want and do not want' (Gibney, 1943a, p. 3). In the very short plan he sketched two 'stress diagrams' of Ireland through which he summarised the situation in 1942 and a future alternative. The first depicted a bleak contrast between Dublin and Belfast as the main economic drivers, and imbalances between the remaining urban and rural areas leading to inequality and poverty. This simplification ignored the poverty that was prevalent in parts of the cities and the diversity between different parts of rural Ireland. The second sketch, with the title 'Tomorrow', proposed a radical change towards balanced development through a reorganisation of the 
settlement pattern and transport networks, involving a new national capital relocated in the centre, north of Athlone. It was envisaged that it could become the administrative capital for a new decentralised model for Ireland, which in his view would be 'conducive to a community outlook, equality of opportunity, national wellbeing and a new system of devolved participatory democracy' (Gibney, 1943a, p. 3). The cities of Dublin, Waterford, Cork, Limerick, Galway, Sligo, Derry and Belfast would be connected via an all-island perimeter route and linked to the central hub via radial routes. In effect, the Gibney proposal, which he summarised in an abstract model, was an attempt to apply the principles of the garden city movement to the whole island of Ireland.

Gibney's long-term vision was informed by an exhaustive personal accumulation of evidence which he presented in more than 330 maps in his Suirbhéaracht Éireann (1943b) as a basis for an Irish National Survey. The Gibney 'Atlas' was ground-breaking not only for the extensive range of topics covered but also for its conceptual and methodological innovations. It established the relative location of Ireland on world maps based on international travel times; introduced the idea of 'urban magnets' with outlines of the extent of their spheres of influence and the connections between Ireland's main centres and international-scale magnets in England and western Europe; and also mapped the distributions of towns that were growing, stagnant or declining in population with supporting explanatory evidence provided by maps of the predominantly radial transport network.

Following the first National Planning Conference and the two Gibney publications, the first National Planning Exhibition was held in the Mansion House in Dublin in 1944 (Bannon, 1989, p. 64). The event was attended by large numbers from many sections of the community, including the Taoiseach and other politicians. Nevertheless, apathy prevailed at a political and administrative level, with deep suspicions expressed in the media in regard to the purpose and potential risks associated with planning. Some excoriating reviews of the exhibition were published by The Irish Times satirist using the pseudonym Myles na gCopaleen, while in reality the same person was the private secretary to the Minister for Local Government with responsibility for Local Planning Schemes by the Local Authorities (MacCabe, 2018).

The extent of the gap between the vision-building process articulated by Gibney and others and that of the leading politician of 
the day, Taoiseach de Valera, was enormous. On 17 March 1943 de Valera, in a radio address to the nation, set out his vision as follows:

The ideal Ireland that we would have, the Ireland that we dreamed of, would be the home of a people who valued material wealth only as a basis for right living, of a people who, satisfied with frugal comfort, devoted their leisure to the things of the spirit - a land whose countryside would be bright with cosy homesteads, whose fields and villages would be joyous with the sounds of industry, with the romping of sturdy children, the contest of athletic youths and the laughter of happy maidens, whose firesides would be forums for the wisdom of serene old age. ${ }^{1}$

This much quoted vision statement was remarkable for what it omitted as much as for the values and nostalgia that it uncritically promoted. The complacent acceptance of frugal comfort at the behest of their political leader by a people residing in cosy homesteads in the countryside and villages ignored the increasing segment of the population living in the towns and cities; the extent to which opportunities to progress were very unequal between different parts of the state; and that a vision for a properly functioning democratic state might need to be achieved through a participative consensus-building process was very much at odds with the evidence-informed dialogue that Gibney advocated. Unfortunately, the disconnect that was evident over seventy-five years ago between some political leaders and those professionally trained to plan and articulate alternative future scenarios is still evident in attempts to achieve coherent implementation of strategic approaches to spatial planning and regional development at different levels, extending from the local to the national scale.

In the late 1950 s and early 1960 s competing discourses began to emerge on how to plan the spatial dimension of economic and social development. The concept of growth poles and growth centres, which had been influenced by the 1950s theories and models of Perroux, Boudeville, Myrdal and Hirschman, were gaining acceptance in many countries (Moseley, 1974) and quickly became the focus of debate in

1 The full text of the de Valera address to the nation is commonly known as 'The Ireland that We Dreamed of' and can be accessed on Wikipedia, which uses the recording of the broadcast held in the RTÉ archives. 
Ireland. Newman (1958), in a seminal paper on the future of rural Ireland, had noted the potential benefits of centralisation of new development in growth centres, but he also warned that the settlement spatial pattern and hierarchy could pose risks for rural areas. Later, pioneering research by rural sociologists in Limerick and west Cork identified the importance of local service centres as nuclei around which future development might be organised. The Committee on Industrial Organisation, with the support of economists such as Garret FitzGerald (1964), was more firmly focused on economic development and strongly favoured concentration in a small number of primary growth centres. The concept of strategic concentration was also adopted in the recommendations of two major reports on education (OECD, 1965) and health (Consultative Council on General Hospital Services, 1968).

It was not until 1963 before the first major legislative framework for planning was adopted in the Local Government (Planning and Development) Act, which was modelled on the approach adopted in England and Wales, where planning was viewed as a regulatory tool with limited concern for the linkage between planning activity and the goals for national socio-economic development. A fundamental weakness in the Act was the absence of any reference to strategic planning at the level of regions. However, the government proceeded to establish nine planning regions, but without any clarity on how planning might be undertaken at this scale. Furthermore, the choice of provisional regional boundaries was not guided by any analysis of functional relationships between places - the geography of the command structure of the Irish army seems to have been the main influence on the choice of boundaries (Bannon, 1989, p. 141).

\section{The Buchanan report and aftermath}

The report by Colin Buchanan and Partners on regional studies in Ireland was published by the government in autumn 1968. It will not be discussed in detail here as it is the subject of a separate paper in this issue by Breathnach. The report exemplifies the dominant rational, positivist and technical planning paradigm which prevailed in Western Europe and North America at this time. While the main recommendation that future growth should be concentrated in a hierarchy of well-distributed growth centres was well received by the economic growth protagonists (O'Neill, 1971), it was quickly portrayed as a threat to rural areas, which was most clearly articulated 
by Newman (1967) during the course of preparing the report. Geographers were also more cautious in their assessment of the growth centre proposal (Breathnach, 1982; O'Farrell, 1971, 1974; Walsh, 1976). The political response sought to avoid inter- and intraregional tensions and ultimately rejected the strategic vision proposed by Buchanan. Instead, in 1969 the government requested the Industrial Development Authority (IDA) to prepare regional industrial plans and thereby initiated a tendency to equate regional development primarily with inward investment-led industrialisation. The IDA plans were exceptionally detailed at the level of regions and town clusters and they also epitomised a prevailing belief that development outcomes could be planned and implemented by technocratically managed organisations. The IDA were in fact very successful in the 1970s in achieving a dispersal of new industrial development (Breathnach, 1982; Gillmor, 1985). However, an unintended legacy of their success was to create a dependency mindset in many of the regions whereby local activists, with the support of national politicians, are still prone to expect the IDA to provide solutions when some companies either close or downsize. A more fundamental legacy from the abandonment of the Buchanan strategy by the government in its 1972 policy statement (NESC, 1975) was the neglect of any policy initiative for the urban system, and in particular a failure to tackle the impacts of the primacy of Dublin on the middletier cities and large towns (McCafferty, 2007, and in this issue).

Another significant missed opportunity was the failure of successive governments to respond to the key recommendations of the Kenny report (Committee on the Price of Building Land, 1973), which sought to regulate the supply and demand for building land and would have curbed the scale of windfall profits for property developers and speculators controlling significant land banks (Bannon, 1989; O'Leary, 2014). Pringle (1989) claimed that the 'prevailing rural ethos' and 'traditional rural outlook' reflected in the property rights enshrined in the Irish constitution was a significant influence on the failure to devise an appropriate urban development policy (Bannon, 1983).

\section{European and other influences}

Further complexity emerged in the 1980s. Following the establishment of the European Regional Development Fund in 1976 there was an important shift in government policy towards treating Ireland as a single region with a reduced focus on interregional disparities in the 
country. The inward industrialisation model pursued by the IDA on behalf of the government was severely criticised in a report for the National Economic and Social Council (NESC, 1982), and the economic recession in the 1980s exposed major weaknesses in the traditional industries in Dublin and also in the inadequacy of the prevailing approach to supporting industrial development in each of the regions (Walsh, 1989). There followed a reprioritisation of the sectors targeted for inward investment and a gradual reorientation towards the larger centres, especially Dublin. The reform of the much enlarged EU Structural Funds in 1988 placed a strong emphasis on inclusion of a bottom-up approach to regional development and provided opportunities and expectations for a reinvigoration of planning at the level of regions. However, the political response was very different - the primary objective of maximising the drawdown by government of EU funds for the whole country was not to be compromised by regional issues. Accordingly, the agency with responsibility for providing technical support for regional development that had been established in 1964, An Foras Forbartha, was abolished in 1987 and so also was the structure of regional development organisations in each of the planning regions which had been in place since 1969. At the same time major urban renewal schemes were launched in Dublin without any assessment of the potential inter- and intra-regional impacts. The first National Development Plan, for 1989-93, which was required to access EU Structural Funds, was characterised by a very feeble attempt to explicitly recognise the regional challenges and instead opted to place the focus of sub-national development initiatives at the local level (Walsh, 1993).

Throughout the 1990s Ireland benefited from access to the European single market and the receipt of substantial amounts of EU Structural Funds. The closer relationship with the EU helped to substantially increase the inflow of foreign investment while the EU Structural Funds were used to improve the national transport infrastructure, large tourism products and waste management infrastructure, and to increase investment in education and training of the workforce. A rapid catch-up was achieved between Ireland and the EU average on economic performance indices but interregional disparities continued to widen (Walsh, 1995). At the same time there was an increasing emphasis on reorienting the national development strategy towards environmental sustainability (Government of Ireland, 1997). 
At the European level there was a major initiative in the 1990s to develop a comprehensive understanding of the forces that were shaping the spatial structure of the economy and society. This culminated in the publication of the European Spatial Development Perspective (ESDP) in 1999, with the sub-title Towards Balanced and Sustainable Development of the Territory of the European Union (Commission of the European Communities, 1999; Faludi \& Waterhout, 2002). It advocated a fresh approach based on principles aimed at achieving a comprehensive and integrated approach to territorial competitiveness, social justice and sustainable development (Haughton et al., 2010). Towards the end of the 1990s a broad consensus began to emerge in Ireland (NESC, 1999), supported by each of the main political parties, that a national spatial strategy was needed (O'Leary, 2003; Walsh, 2007, 2013). The influence of the ESDP principles has already been examined by Walsh (2009).

\section{The National Spatial Strategy (2002) and the National Planning Framework (2018)}

The NSS was published as a government policy document in December 2002 with the subtitle People, Places and Potential. It was a significant milestone in the history of planning in Ireland. Its vision, methodology, content and structure reflected the shifts that had occurred in planning paradigms over the generation since the Buchanan report (Walsh, 2009). As much has already been published on the NSS in a previous issue of this Journal (McCafferty et al., 2013; Morgenroth, 2013; O'Riordain, 2013; Van Egaraat et al., 2013; Walsh, 2013) and elsewhere, the focus here is to compare and contrast the NSS and the more recent NPF for Project Ireland 2040 using the following themes: context, rationale, mission and ambition, preparation methodology, key concepts and themes, population distribution and settlement proposals, and implementation. Much of the discussion is summarised in tables with key points covered in the main text.

\section{Context}

There were significant contrasts between the macro-economic and political contexts in which each of these government policy documents were prepared (Table 1). The NSS was prepared in a period of very rapid economic expansion which was facilitated in part by a series of national development plans and related processes. It was also the 
period during which there was an intensification of a drift towards a neoliberal urban policy and an entrepreneurial approach to planning that had begun in the mid 1980s and that contributed to the transformation of settlement both within and in the hinterlands of the largest cities, especially Dublin (Bartley, 2007; MacLaran \& Kelly, 2014). The move towards a neoliberal approach to planning was part of a wider revision in Ireland and in other countries (Allmendinger, 2009) of the relationship between the state and development, which included a retreat from a focus on welfare equality and its replacement with a greater emphasis on supports for a competitive marketorientated state and incentives for those who create wealth without much regard for any negative social or environmental impacts. The objectives and methodologies of planning were also evolving, with greater emphasis on sustainability and on the potential of strategic spatial planning. At a political level the Good Friday Agreement, 1998, provided an additional impetus for greater coordination of spatial planning on an island-of-Ireland basis (Walsh, 2005). Unfortunately, the high expectations that accompanied the publication of the NSS were not achieved for many reasons, including a lack of consistency in support across government departments; the legacy impact of the implementation of poor planning decisions made in the context of the drift towards neoliberalism prior to the NSS; the weaknesses in governance structures, especially at the regional level (Breathnach, 2013; O'Riordain, 2013), which have contributed to development-led plans; and lastly the drastic change in the overall macro-economic context after 2007. ${ }^{2}$

A conference organised by the Regional Studies Association (Irish Branch) in 2012 - ten years after the launch of the NSS - concluded that, given the limited achievements, a new approach to strategic spatial planning was urgently needed to avoid in the future the unsustainable outcomes that had emerged over the previous two decades (Walsh, 2013). In the meantime, the government had also embarked on a major reform of local government, which included provision for a strengthened tier of strategic planning at the level of three regions (Government of Ireland, 2012). The theoretical and technical knowledge base to underpin the NPF was also more advanced than it had been for the NSS. At a political level the relationship with Northern Ireland had become more complex and

${ }^{2}$ For a comprehensive assessment consult the papers in the 2013 special issue of Administration (vol. 60, no. 3). 
uncertain in the context of the UK decision in 2016 to leave the EU and also in the absence of a functioning Northern Ireland Assembly, while at a domestic level the confident and populist stance of the government that produced the NSS was replaced by a strongly committed minority government, which had to be more cautious in relation to decisions that entailed political risks.

\section{Table 1: Context for the National Spatial Strategy and the National Planning Framework}

\begin{tabular}{|c|c|}
\hline & \\
\hline $\begin{array}{l}\text { ecedented } \\
\text { d } \\
\text { l and } \\
\text { ts, but also } \\
\text { ribution of } \\
\text {; } \\
\text { - period of } \\
\text { substantial } \\
\text { nd; } \\
\text { ean Spatial } \\
\text { tive } \\
\text { troduced } \\
\text { ovided an } \\
\text { ctive; } \\
\text { nable } \\
\text { published } \\
\text { Planning } \\
\text { 010, which } \\
\text { ork for } \\
\text { ning } \\
\text { luction of } \\
\text { essential } \\
\text { tuthority } \\
\text { o ensure } \\
\text { JSS } \\
\text { a broad } \\
\text { ide range }\end{array}$ & $\begin{array}{l}\text { hat the } \\
\text { f } \\
\text { y but } \\
\text { of } \\
\text { to } \\
\text { diture; } \\
\text { in } 2014\end{array}$ \\
\hline
\end{tabular}


Table 1: Context for the National Spatial Strategy and the National Planning Framework (Contd.)

\begin{tabular}{|c|c|}
\hline $\mathrm{Na}$ & $\mathrm{Na}$ \\
\hline $\begin{array}{l}\text { Regional Studies Association, } \\
\text { the ESRI (Fitzgerald et al., } \\
\text { 1999) and NESC (1999); } \\
\text { - National Development Plan } \\
\text { 2000-2006 - included first } \\
\text { commitment by government to } \\
\text { prepare an NSS and provide a } \\
\text { framework to guide } \\
\text { implementation of national } \\
\text { development plans; } \\
\text { Good Friday Agreement, 1998, } \\
\text { provided an imperative for } \\
\text { coordination of spatial planning } \\
\text { strategies and for collaboration } \\
\text { on major publicly funded } \\
\text { infrastructural projects for the } \\
\text { island of Ireland; } \\
\text { Comparatively weak knowledge } \\
\text { base regarding spatial patterns } \\
\text { and the underlying causes; } \\
\text { Strong initial support from } \\
\text { confident and populist } \\
\text { government. }\end{array}$ & $\begin{array}{l}\text { preparation of regional spatial and } \\
\text { economic strategies; } \\
\text { - Government commitment that NPF } \\
\text { Project Ireland } 2040 \text { would be } \\
\text { underpinned by a National } \\
\text { Investment Plan, which would be } \\
\text { aligned with the strategic direction of } \\
\text { the NPF; } \\
\text { - Prospect of Brexit and wider move } \\
\text { towards renationalisation of trade, } \\
\text { leading to increased uncertainty with } \\
\text { implications for national and } \\
\text { regional economies; } \\
\text { - Relationship with Northern Ireland } \\
\text { had become more complex and less } \\
\text { confident; } \\
\text { Increasing emphasis at EU and } \\
\text { OECD on paradigm shift towards } \\
\text { place-based strategies; } \\
\text { - More comprehensive and } \\
\text { sophisticated knowledge base; } \\
\text { - Minority government that was more } \\
\text { cautious but with strong commitment } \\
\text { to the Ireland } 2040 \text { project. }\end{array}$ \\
\hline
\end{tabular}

\section{Rationale}

The immediate rationale for both the NSS and the NPF was a need to strengthen the planning system in order to cater for substantial anticipated increases in population and employment; to anticipate a significant increase in housing demand and plan for its geographical distribution; and to achieve an improved and more sustainable balance between Dublin and the remainder of the country in all aspects of development. In each instance there was a reactive element to address a broad range of economic, social and environmental outcomes that had become unsustainable. The NSS was a first step in changing how planning at all levels was organised and implemented. A key proposition was that a coherent, nested hierarchical approach to planning could assist in addressing a modest number of key policy questions. The rationale for the NPF is broader and more radical, with 
a greater sense of urgency about several discrete but interrelated issues that had become more critical in the era of austerity (Table 2). The key proposition is that a new paradigm is needed to replace a continuation of the 'business as usual' approach which is considered to be no longer sustainable on any dimension of development.

\section{Table 2: Rationale for the National Spatial Strategy and the National Planning Framework}

\begin{tabular}{|c|c|}
\hline National Spatial Strategy & National Planning Framework \\
\hline $\begin{array}{l}\text { - Strengthen the national } \\
\text { planning system in order to } \\
\text { respond to the new socio- } \\
\text { economic geography of Ireland } \\
\text { in the } 1990 \text { s, and to facilitate a } \\
\text { more sustainable approach to } \\
\text { development for a rapidly } \\
\text { expanding population and } \\
\text { workforce; } \\
\text { Achieve a better balance in all } \\
\text { aspects of development } \\
\text { between Dublin and other cities } \\
\text { and between the cities and rural } \\
\text { areas; } \\
\text { Facilitate a reduction in } \\
\text { regional economic disparities } \\
\text { and a move towards fewer } \\
\text { workers having to commute } \\
\text { over long distances. }\end{array}$ & $\begin{array}{l}\text { - Plan for a further significant increase } \\
\text { in population, housing and } \\
\text { employment; } \\
\text { - Link health and well-being of all } \\
\text { members of society regardless of } \\
\text { location; } \\
\text { - Achieve a better alignment of } \\
\text { spatial/location strategies of social } \\
\text { services, and cater for a more diverse } \\
\text { society; } \\
\text { - Support the achievement of } \\
\text { compliance with environmental } \\
\text { obligations in relation to air, water, } \\
\text { biodiversity and habitats; } \\
\text { - Adapt to climate change and support } \\
\text { achievement of targets regarding } \\
\text { emissions, renewables and efficiency; } \\
\text { - Address issues related to settlement } \\
\text { patterns, including urban sprawl, } \\
\text { growth corridors, long-distance and } \\
\text { time-consuming commuting, } \\
\text { hollowing out of town centres, } \\
\text { pressures in accessible rural areas } \\
\text { and rural decline in other parts. }\end{array}$ \\
\hline
\end{tabular}

\section{Mission and ambition}

The NSS was a twenty-year strategy designed to achieve a better balance of economic, social and physical development and population growth between regions. It envisaged that through a closer matching of where people live with where they work, different parts of Ireland would be able to sustain a better quality of life, a strong competitive economic position and an environment of the highest quality. The key policy objective was to reduce the disparities between and within the 
two regional assembly regions and develop the potential of both to contribute to the greatest possible extent to the continuing prosperity of the country. By contrast, the overarching goal of the NPF is to achieve 'a roughly 50:50 distribution of growth between the Eastern and Midland region, and the Southern and Northern and Western regions, with $75 \%$ of the growth to be outside of Dublin and its suburbs' (Government of Ireland, 2018, p. 11). This is more specific in relation to interregional balance but there is very little mention of intra-regional imbalances despite the difference in scale between the three macro regions and the previous nine planning-level regions. The ambition of the NPF is much greater than addressing the issues related to differences between regions. The overall vision is captured in the Foreword by Taoiseach Leo Varadkar, which states that 'Project Ireland 2040 National Planning Framework represents an important shift from previous approaches to long-term planning and investment by Government. It is an approach that joins up ambition for improvement across different areas of our lives, bringing the various government departments, agencies, State owned enterprises and local authorities together behind a shared set of strategic objectives for rural, regional and urban development' (Government of Ireland, 2018). The contrast between the multidimensional, multiagency and territorial inclusiveness of this vision and that of his predecessor in the 1940s, quoted earlier, could hardly be more different. Furthermore, the political vision articulated in the NPF is well grounded in the experience and advice from the senior professional planners.

In practice, it is envisaged that the NPF will provide 'a framework to guide public and private investment, to create and promote opportunities for our people, and to protect and enhance our environment at different scales across the entire territory from our villages to our cities, and everything around and in between' (Government of Ireland, 2018, p. 10). A notable difference between the final published NPF and an earlier draft prepared for wider consultation was the omission of a section on values (some might be more appropriately regarded as principles or goals) to support the NPF vision, though many are interspersed throughout the final NPF text. The values-driven approach was advocated by the NPF Expert Advisory Group and included:

- equality of opportunity, social cohesion and converging living standards throughout the country; 
- sustainable choices and options for people, businesses and communities;

- quality in all aspects of life, underpinned by high-quality and wellmanaged built and natural environments;

- a creative, innovative and culturally attuned society;

- connectivity to underpin competitiveness of businesses and quality of life of people, communities and regions;

- a collaborative society based on partnerships between cities, towns and other areas;

- a capacity for sustainable self-reliance based on a strong circular economy; and

- commitment to being the most successful, advanced, competitive and environmentally sustainable economy and society in Europe (Government of Ireland, 2017, p. 18-22).

The values or principles approach was adopted in order to articulate what the scope of the NPF might be and to place the emphasis on a framework to which other government policies and strategies could be aligned in the future. In this way it was envisaged that the NPF could replace the function previously performed by the national development plans. The main difference is that in the national development plans the spatial strategy objectives were to be achieved through a coordination of sectoral and other policies whereas the NPF provides the overarching framework for the policies of all other government departments and the agencies linked to them. Implementation is supported by a National Investment Plan, which is aligned with the NPF objectives and which was published simultaneously with the NPF.

\section{Preparation methodology}

At an operational level a broadly similar approach was adopted for the preparation of both documents. In each case the process was led and coordinated by a small group within the government department with advisory support provided by expert panels - which was much broader in the case of the NPF - and additional technical support drawn from external sources. There was also a multistage consultation process for both documents (Table 3).

The background technical research for the NPF had a stronger focus on economic theories of regional development, which was complemented by cartographic representation and analysis of demographic and socio-economic indicators and also by national and regional demographic projections. In contrast to the NSS, the NPF 
Table 3: Preparation of the National Spatial Strategy and the National Planning Framework

\begin{tabular}{ll}
\hline \multicolumn{1}{c}{ National Spatial Strategy } & \multicolumn{1}{c}{ National Planning Framework } \\
\hline - Small unit in Department of the & - Small unit in Department of \\
Environment, Heritage and & Housing, Planning and Local \\
Local Government; & Government; \\
- Expert Advisory Group; & - Lessons from NSS implementation; \\
- Sequence of 'issues' papers & NSS Review Group report published \\
focus especially on balanced & in 2014; \\
regional development and & - Expanded Expert Advisory Group; \\
functional areas; & - Issues and Choices paper; Draft of \\
- Presentations; public & entire NPF with SEA and NATURA \\
consultation and submissions & impact statement and flood risk \\
invited; & assessment reports; \\
- Extensive research programme & Presentations, consultations and \\
to provide baseline evidence - & submissions; \\
strong geographical/spatial & - Research on regional development \\
focus; & models with emphasis on economic \\
- Regional meetings and & analysis of agglomeration/urban size \\
presentations; & and cities as drivers; cartographic \\
Briefings/negotiations with & representation and analysis of \\
other government departments; & demographic and socio-economic \\
Engagement with political & indicators; national and regional \\
parties and individuals and & demographic projections; \\
management of lobbying. & - Consideration of alternative \\
& - Bcenarios; \\
& - Eriefings/negotiations with other \\
& angagement with political parties \\
& and individuals, and management of \\
&
\end{tabular}

contains very few maps; instead there is an overabundance of photographs. The absence of maps from the NPF is compensated to an extent by many high-quality maps in the Strategic Environmental Assessment Report for the NPF (Department of Housing, Planning and Local Government, 2017a). A number of macro-spatial options were assessed in relation to the balance between regions, concentration versus dispersal and compact growth versus sprawl, while also considering how these alternatives could be aligned with infrastructure delivery and what instruments would be required to achieve effective strategic coordination in implementation (Hogan, 2018). Compre- 
hensive strategic assessment reports were commissioned in relation to the environment and flood risks, with an additional Natura Impact Statement (Department of Housing, Planning and Environment, 2017a, b, c). These reports contain a large number of maps and other data that informed the rigour underpinning the NPF proposals. The Strategic Environmental Assessment Report, in particular, includes a multicriteria evaluation of each of the alternative strategic scenarios, and for the preferred scenario it also assesses the potential for achieving the ten national strategic outcomes (NSOs).

The narrative in the NPF is less theoretical and contains fewer abstract concepts, and there is greater clarity on selection of named centres and more emphasis on the national priorities to be supported later by RSESs, including metropolitan area strategic plans (MASPs). It exemplifies an adherence to best-practice principles for strategy development - clarity regarding ambition and objectives, prioritisation, a focus on achievable essentials rather than on aspirational alternatives, coherence between objectives, and being informed by evidence and good practice. It represents a continuation and further elaboration of the transition in planning practice from the predominantly positivist/technocratic model of earlier decades (Allmendinger, 2009; Walsh, 2019) to a more pluralist practice that also embraces aspects of the post-modern paradigm such as visioning, mediation, combining expert and experiential knowledge, participation, and shared understanding of different roles and meanings of places and spaces.

\section{Key concepts and themes}

The NSS, following the approach of the ESDP (Commission of the European Communities, 1999), promoted an alternative perspective on balanced regional development that involved a move from a focus on reducing uneven distributions to enabling local and regional potentials, but the concept was not well defined and no mechanisms were identified for leveraging potential (Table 4).

The NPF is more specific on a modified concept of 'effective regional development' that aims to achieve 'regional parity', which is defined as 'a more credible, reasonable and viable alternative scenario, whereby the targeted growth of the Northern and Western and the Southern Regional Assembly areas combined would exceed that projected under a "business as usual" scenario and would at least equate to that projected for the Eastern and Midland region' (Government of Ireland, 2018, p. 26). 
However, the risk of increased intra-regional imbalance is not addressed. The NPF is guided by the place-based development paradigm (Barca, 2009) and involves a deeper and more comprehensive assessment of the components of quality of life, greater specificity in relation to environmental sustainability accompanied by a Strategic Environmental Assessment Report, plus stronger and potentially more effective actions to support implementation. While the NPF relies very much on the second-tier cities and some other regional towns to achieve the regional parity objective, it is important to note that other spatial configurations can also support effective regional development, as evidenced by the success of the 'Wild Atlantic Way' tourism initiative.

Table 4: Key concepts and themes in the National Spatial Strategy and the National Planning Framework

\begin{tabular}{ll}
\hline \multicolumn{1}{c}{ National Spatial Strategy } & National Planning Framework \\
\hline - Balanced regional development & - Centrality of 'planning' and \\
based on potential without & 'framework' in the title and removal \\
compromising national & of 'spatial' from the discourse; \\
competitiveness and economic & - Effective regional development \\
performance; & linked to 'regional parity'; \\
- Functional areas vs. & Explicit focus on second-tier cities as \\
administrative units; & part of strategy to decelerate the \\
- Achieve critical mass for & expansion of Dublin and accelerate \\
provision of public and private & city-led development elsewhere; \\
services in designated urban & avoidance of terminology such as \\
centres (gateways and hubs), & gateways, hubs, polycentric and \\
and respond to diversity of & strategic spatial roles; \\
rural areas; & Late addition of Border and \\
- Promote two major & Midland towns but without specific \\
axes/corridors of economic & targets; \\
development: Dublin to Belfast & - Place-making: stronger urban places \\
and Cork to Galway; & and diverse rural places; \\
polycentric gateway in & Q Quality of life: people, homes and \\
Midlands; & communities - supporting health \\
- Includes border frontier & and well-being, access to education, \\
gateways at Dundalk, Sligo and & housing, plus diversity and \\
Letterkenny; & inclusiveness across age groups at \\
- & appropriate scales in both urban and \\
different parts of the country & rural contexts; \\
based on typology of rural areas & Integration of terrestrial and \\
as alternative to functional & offshore planning; \\
areas; & \\
\hline &
\end{tabular}


Table 4: Key concepts and themes in the National Spatial Strategy and the National Planning Framework (Contd.)

\begin{tabular}{ll}
\hline \multicolumn{1}{c}{ National Spatial Strategy } & National Planning Framework \\
\hline - Connectivity - radial and & - Transnational coordination and \\
linking corridors plus & cooperation; \\
international access points; & - Transition to an environmentally \\
- Northern Ireland connectivity & sustainable future; \\
and coordination of spatial & - Strategic environmental assessment, \\
plans; & including alternative scenarios; \\
- Utilities: increase capacity of & - Strengthening the planning process \\
electricity and gas distribution & via metropolitan area strategic plans \\
networks; & and regional spatial and economic \\
- Support for economic sectors - & strategies, integration of spatial and \\
manufacturing enterprises, & transport planning; National \\
tourism, and others; & Regeneration and Development \\
- Housing in different types of & Agency; Planning Regulator Office; \\
urban and rural areas; & Implementation - more effective \\
- Services to support quality of & planning system with additional \\
life in different areas; & statutory supports, regional spatial \\
- Intra-regional plans: outlined & and economic strategies, alignment \\
on maps; & of public capital investment, \\
- Implementation: new structures & statutory support. \\
as drivers; statutory support as & \\
required, requirement that & \\
other plans demonstrate & \\
consistency with the NSS; & \\
regional planning guidelines for & \\
all regions; support for & \\
gateways and hubs. & \\
\hline
\end{tabular}

\section{Population distribution and settlement proposals}

The future settlement pattern and spatial distribution of the population will be a key influence on whether the NPF can achieve the full suite of integrated NSOs (Government of Ireland, 2018, p. 13). These include especially the proposed outcomes in relation to managing a transition to a low-carbon and climate-resilient society, sustainable mobility patterns, access to services, compact growth and sustainable management of water, waste and other environmental resources. It is likely that trends in population distribution and settlement will become an important indicator of the success of the NPF as the relevant data will become available from the census of population. 
There is a radical difference between the NSS and the NPF in how they envisage the regional distributions of future population increases. The NSS was guided by a projection of 5.03 million for the total population in 2020, an increase of 1.4 million (39 per cent) over the 1996 total. Approximately 56 per cent $(c .800,000)$ of the total increase was anticipated to occur in the Greater Dublin Area (Dublin plus the Mid-East regions). An increase of another c.300,000 was envisaged in the four second-tier cities and their hinterlands (Cork, Limerick, Galway and Waterford), with only 12 per cent of the total increase expected in all other parts of the country. The scale of further concentration in the cities that was implicit in the NSS was not always widely appreciated as the strategy was criticised by some for opting for too many gateways and hub towns.

The NPF is guided by a projection of c.5.8 million for the total population in 2040, which would be an increase of 1,045,000 (22 per cent) from 2016. This scale of increase will in fact be lower than the increase of 1,136,000 (31 per cent) that occurred over the previous 25year period, 1991-2016. Table 5 compares the increases that occurred in each of the three regions between 1991 and 2016 and the projected increases for 2016-40. The greatest adjustment is envisaged for the Eastern and Midland region (which includes County Louth), where the projected increase of 515,000 is 110,000 fewer than over the previous 25 years and implies a curtailment of the relative level of increase from 36.7 per cent to 20.3 per cent. No change is envisaged in the rate of increase in the Southern region even though the projected actual growth is 30,000 more than in 1991-2016. This reflects the importance attached to the second-tier cities, with three of the four located in the Southern region. Further growth is anticipated in the Northern and Western region, though at a much slower pace: 18 per cent versus 27 per cent achieved between 1991-2016.

The scale of the projected interregional adjustment can be gauged by comparing the projections with a continuation of 'business as usual' scenarios (Table 6). Despite the significant adjustment implied by the $\mathrm{NPF}$, the interregional distribution of the total population will change by very little from the 2016 baseline and it is notable that the relative gain in the Southern region will be achieved by comparable levels of relative deceleration projected for both the Eastern and Midland and the Northern and Western regions, notwithstanding their very different potentials. A 'business as usual' scenario that involves a continuation of the trend in redistribution established over the period 1991-2016 implies an increase of almost 400,000 above the NPF target 
Table 5: Population increase 1991-2016 and projected increase 2016-40 by region

\begin{tabular}{lcccc}
\hline Region & $\begin{array}{c}\text { Population } \\
\text { 2016 }\end{array}$ & $\begin{array}{c}\text { 1991-2016 } \\
\text { \% change }\end{array}$ & $\begin{array}{c}\text { NPF target } \\
2040\end{array}$ & $\begin{array}{c}\text { 2016-40 } \\
\text { \% change }\end{array}$ \\
\hline Eastern and Midland & $2,328,517$ & 36.7 & $2,800,000$ & 20.3 \\
Southern & $1,585,906$ & 26.3 & $2,000,000$ & 26.1 \\
Northern and Western & 847,442 & 27.0 & $1,000,000$ & 18.0 \\
Ireland & $4,761,865$ & 31.3 & $5,800,000$ & 21.8 \\
\hline
\end{tabular}

to 55 per cent in the share of the total population residing in the Eastern and Midland region, and a decline of 311,000 less than the NPF target to 29.1 per cent in the Southern region. If the 'business as usual' scenario is confined to the trend of greater concentration in the Greater Dublin Area that was established in the most recent intercensal decade, the share of the total population residing in the Eastern and Midland region could increase to 58.1 per cent while the share in the Southern region could decline to 27.4 per cent. It is the implications of these potential trends, unless some corrective actions are taken, that provide the raison d'être for the NPF.

Table 6: Percentage distribution of population by region 2016, under NPF targets and alternative scenarios

\begin{tabular}{lcccc}
\hline Region & $\begin{array}{c}\text { Population } \\
2016\end{array}$ & $\begin{array}{c}\text { NPF target } \\
2040\end{array}$ & \multicolumn{2}{c}{$\begin{array}{c}\text { 'Business as usual' } \\
\text { scenarios }\end{array}$} \\
\cline { 4 - 5 } & & & $1991-2016$ & $2006-16$ \\
\hline Eastern and Midland & 48.9 & 48.3 & 55.0 & 58.1 \\
Southern & 33.3 & 34.5 & 29.1 & 27.4 \\
Northern and Western & 17.8 & 17.2 & 15.8 & 14.6 \\
Ireland & 100.0 & 100.0 & 100.0 & 100.0 \\
\hline
\end{tabular}

The feasibility of achieving the adjustments envisaged under the NPF needs to be assessed against established trends in the components of population change: natural increase and net migration. Over the twenty years between 1996 and 2016 natural increase accounted for 62 per cent $(691,000)$ of the total population increase in Ireland. The contribution was broadly similar in the Eastern and Midland (64 per cent) and Southern regions (67 per cent) but it was much lower in the Northern and Western region (51 per cent), presumably due to the older age profile. The prospect of slowing the rate of increase in the Eastern and Midland region and of enabling the 
Southern region to increase its share compared to what might occur under a 'business as usual' scenario is very much dependent on the capacity to influence net-migration patterns. Between 1996 and 2006 the Eastern and Midland region attracted 51.5 per cent of all international and interregional migrants compared to 28.4 per cent for the Southern region and 20.1 per cent for the Northern and Western region. However, a significant change occurred between 1996-2006 and the more recent decade (Table 7). The experience of the two decades was very different. Almost four-fifths ( 79 per cent) of the total net-migration occurred in the first decade in an era of very rapid economic expansion, whereas in the much less favourable macroeconomic context of the last decade, immigration declined and emigration increased, leading to a net emigration of approximately 28,600 between 2006 and 2016.

Table 7: Percentage distribution of net migration to the three regional assembly areas, 1996-2006 and 2006-2016

\begin{tabular}{lcccc}
\hline Region & Total & \multicolumn{3}{c}{ Percentage share of total } \\
\hline & $1996-2016$ & $1996-2016$ & $1996-2006$ & $2006-16$ \\
\hline Eastern and Midland & 221,079 & 51.5 & 47.1 & 67.8 \\
Southern & 122,152 & 28.4 & 31.5 & 16.9 \\
Northern and Western & 86,336 & 20.1 & 21.4 & 15.3 \\
Ireland & 429,567 & 100.0 & 100.0 & 100.0 \\
\hline
\end{tabular}

The Eastern and Midland region benefited mostly from net migration in the last decade, increasing its share of the total to 68 per cent while the shares of each of the other two regions declined. The increase in the Eastern and Midland region was primarily due to net in-migration of 26,500 to Dublin (comprising all four local authority areas), which doubled its share of the region total from 21.8 per cent to 43.4 per cent. The trends summarised here point towards the beginnings of more compact development in the Eastern and Midland region in line with a key objective of the NPF, but they also pose a very significant challenge to the objective of rapidly expanding the secondtier cities in the other regions - the former South-West planning region, which includes the second-largest city, was the only other planning region to experience net in-migration between 2011 and 2016 and the number was small at 418, one-twentieth of the number for Dublin. The projected increase of 200,000 in the combined populations of the three Southern region cities (Cork, Limerick and 
Waterford) will require a significant reversal of recent net-migration flows and will still account for only 55.6 per cent of the total increase projected for the region. In the Northern and Western region the projected increase of over 50 per cent in Galway city will account for only 25 per cent of the projected increase in the whole region.

The likelihood of increasing net migration to the regions beyond Dublin will depend on many factors, including the availability of suitable employment opportunities, the relative cost of housing and the provision of a wide range of high-quality public and private services, amenities and environments to enhance the quality of life for a more mobile and better-educated population. While many of the actions contained in the NPF are directed at achieving these outcomes, there are significant risks that the high-level objective of regional parity will not be achieved. The NPF, therefore, wisely commits to regular monitoring and review of targets after the 2026 census of population. Given the magnitude of the challenges in the NPF and taking account of the need for a transitional period to get beyond the impacts of some legacy planning decisions, it may be more appropriate to measure progress away from what might occur under a 'business as usual' scenario rather than towards the NPF targets. The enormity of the challenges involved in rebalancing the future regional distribution of the population is reinforced by the most recent regional population projections prepared by the Central Statistics Office, which signal the possibility of further concentration in the Eastern and Midland region (Central Statistics Office, 2019).

The NPF will be supported by three RSESs and by the long-established practice of county development plans, which include 'core strategies' that will be aligned with the RSESs and the NPF. The RSESs are an important innovation in planning practice as a means of devolving some responsibilities from the centre, and also of facilitating a more strategic approach across groups of local authority areas in order to achieve the critical mass required to bring about the objective of effective regional development in pursuit of interregional parity. These strategies are intended to replace the previous regional planning guidelines that were elaborated following the NSS. Furthermore, their scope has been extended to include economic strategies for the regions. Draft RSES documents have been prepared with a high participation of regional-level stakeholders and are currently being revised (April 2019) following public consultation. As expected, each of the draft strategies is guided by the high-level objectives and anticipated national outcomes that the NPF seeks to 
achieve. The preparation of each was guided by population projections to 2031 for each local authority area. Baseline maps and 2016 population totals were also prepared for the metropolitan area of Dublin and each of the other four second-tier cities (Department of Housing, Planning and Local Government, 2018).

The RSES indicative population projections are not intended to be prescriptive. The projected increase between 2016 and 2026 for the entire Eastern and Midland region is 12.5 per cent, which varies from 11 per cent for each of the Midland counties to 12.8 per cent for the Eastern planning area (Mid-East plus Louth), but with a range from 10.6 per cent for Wicklow to 14.2 per cent for Kildare. For Dublin, an increase of 12.6 per cent is projected with no variation between the four local authority areas. The projected increase between 2016 and 2026 for the Southern region is 14.8 per cent. While the projections cater for faster growth in the counties with cities, there is a remarkable uniformity of about 11 per cent in the growth projections for each of the counties without cities. This is similar to the projection for the Midland counties and is repeated for all counties in the Northern and Western region except Galway. While these are indicative projections for each region, the levels of intraregional uniformity do not take account of previous trends over the past decade or longer periods and therefore do not clarify or provide a rationale for the level of adjustment that might be expected in each local authority area. The guidance from the department is interpreted by some counties as requiring an abrupt departure from the established trends, which has become a source of local frustration.

The most important centres in each of the three regions are the cities plus the strategically important towns of Sligo and Letterkenny in the Northern and Western region and of Athlone, Dundalk and Drogheda in the Eastern and Midland region. In addition to the five cities and five regional towns, the three draft RSES documents identify another thirty-three key centres spread across all counties. This approach is delving down to centres that in some instances might be more appropriately identified as priority towns in county development plans. These decisions may have been partially influenced by the geographical distribution of members of the regional assemblies. There is an inherent risk that regional-level interventions will be confined mostly to the largest centres, even though there may be cases where large parts of a region are beyond the sphere of influence of the cities. For example, in the Southern region almost all of County Kerry is beyond the daily sphere of influence - measured by 
commuting patterns - of either Cork city or Limerick city. The core towns of Tralee and Killarney are included in a list of towns that also includes smaller centres such as Nenagh and Newcastlewest, even though the regional importance of the latter two is much less. Indeed, there may be a strong case for equating the role of Tralee with that of Sligo town, which is accorded special status in the Northern and Western region.

The MASPs are a very important component of the RSES documents. Baseline maps have been prepared, which are based mostly on census enumeration districts, and population totals for 2016 have been calculated, which will be important for future monitoring of the implementation of the RSESs and the NPF. However, there is no evidence provided in the RSESs or in the department's Implementation Roadmap (Department of Housing, Planning and Local Government, 2018) on trends over recent decades in the populations of each MASP area and how they may compare with trends in districts immediately beyond the MASP. For example, the boundary for the Dublin Metropolitan Area has not been revised from the map for the Regional Planning Guidelines for the Greater Dublin Area 2010-2022. Only 6 per cent of the population of County Meath resides within the MASP boundary compared to 28 per cent for Kildare, while very rapid expansion occurred more widely in recent times in towns such as Ashbourne, Ratoath and Dunshaughlin in south-east Meath. These settlements share demographic profiles and linkages to Dublin city and other employment zones in County Dublin that are very similar to those in north Kildare. The objective of curtailing the MASP boundary is to encourage more compact future development but this objective may be frustrated if recent trends and further planned developments beyond the boundary are ignored. A more detailed analysis of the MASPs is beyond the scope of this paper.

\section{Implementation}

The implementation proposals for the NPF have been informed by the experience gained from the NSS. The NSS relied heavily on a cabinet subcommittee and an interdepartmental committee of senior officials to provide the necessary driving force and there was a commitment to provide any statutory support that was deemed necessary, though in practice it never happened. The regional authorities were required to take account of the NSS, though this proved to be a weak requirement. Much was expected of the regional planning guidelines and of the extent to which county development plans would be aligned with them. 
A regional innovation fund was established to support the development of the gateways and hub towns.

In practice, however, the NSS encountered many challenges. There remained in some parts of the country and among some politicians an anti-urban bias, which was rooted in the legacy of opposition to the earlier Buchanan growth centres, and also to some extent in the success of the IDA regional plans in the 1970s, which created unrealistic expectations on the capacity to disperse new inward investments even though the sectoral composition and requirements of new companies had changed considerably. The traditional perspective on balanced regional development based on redistribution and the goal of interregional equity persisted and made it more difficult to promote an alternative perspective based on regional potential. The significance of agglomeration economies was poorly understood by many responsible for the overall implementation and especially by those who favoured an approach that involved less concentration in Dublin and the other cities. The expectation of a consistent and shared commitment to supporting the NSS was not upheld, most notoriously by the announcement by the Minister for Finance of a decentralisation plan for employment in public services that was at variance with the strategic spatial approach contained in the NSS. The inconsistency in government support was further compounded by the withdrawal of the gateway innovation fund and a reluctance to devolve effective authority, resources and responsibility from the central administration to the regional authorities (Breathnach, 2013; O'Riordain, 2013). The onset of the national economic crisis just five years after the launch of the NSS proved to be its death knell as government priorities shifted to managing the national recovery through a lengthy phase of austerity policies and programmes.

The implementation structures for the NPF are more complex and are intended to be more robust. The overall framework is designed to achieve ten NSOs which are elaborated via seventy-five national policy objectives. The NPF asserts that there is a significant alignment between the NSOs and the 2015 UN Sustainable Development Goals in areas such as climate action, clean energy, sustainable cities and communities, economic growth, reduced inequalities, innovation and infrastructure, as well as education and health. Of course, each of these areas will require specific interventions that will need to be coordinated at national, regional and local levels. Furthermore, the government's strategic investment priorities in the National 
Development Plan for the next ten years were published simultaneously with the NPF and are aligned with the planned NSOs. The national framework will be supported by the three RSESs, which will include five MASPs.

The planning system has been strengthened by providing statutory underpinning for the NPF, and the establishment of a Land Development Agency and an independent Office of the Planning Regulator (in response to the Mahon report - Tribunal of Inquiry into Certain Planning Matters and Payments, 2012) with responsibility for oversight of the planning system at all levels and for advising the minister, government and the Oireachtas on the implementation of the framework. It is too early to assess the potential impact of these changes. However, it is likely that in practice many challenges will arise through which individual and organisational self-interest may seek to frustrate the achievement of outcomes for the betterment of society as a whole. Specific new funding arrangements have been established for the regeneration of the urban and rural economies. These are potentially very important innovations designed to ensure that the multilevel planning system delivers on the objectives that need to be achieved in order to break away from a continuation of the 'business as usual' models of recent decades.

The NPF attaches considerable importance to a place-based approach to planning at all geographical scales, as advocated by Barca (2009) and Barca et al. (2012). The ever-increasing body of academic literature on this topic suggests many conditions are necessary for a successful implementation of place-based strategies. These include (a) adopting a broad concept of development for all of society, encompassing social, cultural, economic and environmental dimensions and how they can be mutually supportive; (b) facilitating the valuing and sustainable harnessing of local resources of all types; (c) developing effective partnerships with shared ambitions and mutual trust and respect; and (d) leadership that can articulate and also secure and maintain support for a clear vision, be an advocate, win resources in a competitive context, nurture partnerships internal and external to the area, and address major challenges (Beer et al., 2019). The NPF sets out a broad concept of development for all of society. The remaining conditions are dependent on multilevel leadership, management and governance to ensure effective placebased implementation. In order to bring about the broad behavioural adjustments required at the levels of individuals, organisations and institutions in relation to activities impacting on the public good it will 
be necessary to supplement the capital investments supported via the National Development Plan with a programme of investments in 'soft' capacity building. A monitoring framework to measure progress in this area will need to be established.

\section{Conclusions}

This review has sought to demonstrate that there have been several attempts to articulate visions and plans for Ireland that extend back over many decades. The importance of context and the likelihood of a plurality of visions at different times have been evident over the seventy-five years between 1943 and 2018. It has also been demonstrated that the visions of leading politicians may not always be closely aligned with those of professional planners - this was clearly evident in the 1940s and most recently in the final months of preparing the NPF when intensive lobbying contributed to departures from the proposals of the planners.

The political ideological context for state engagement with regional planning has changed profoundly from a state-led, interregional welfare redistribution approach to a more neo-liberal and entrepreneurial ideology that provides for different formulations of opportunities and threats in each region. On a broader scale, globalisation of production, consumption and distribution systems has become an increasingly important source of differentiated transformation of regions and has resulted in changes in the relationship between Dublin and the rest of the country at different times. The practice of planning, including the methodologies employed and the roles of individual planners, has evolved from technocratic prescription and shaping to more inclusive and collaborative facilitation of plan-making (this was particularly evident in the different approaches adopted for the Buchanan report and the later strategies and framework).

The understanding of space and place has moved from a neutral Euclidean perspective to a greater appreciation of the extent to which places are socially and politically constructed as nodes in global production and consumption networks, and there is more emphasis, especially in the NPF, on the importance of place as the lived-in arena' for life and livelihood. In both the NSS and NPF there is an enhanced awareness of the extent to which functional spaces are fluid and based on networks that are less place-bound, and are also not congruent with administrative areas, with related challenges for both 
analysts and practitioners trained in the positivist tradition and methodologies. The review has also demonstrated a tendency for acceptance without sufficient critique of concepts and models from other contexts that need to be empirically tested for their suitability in the context of Ireland: examples include the Perroux and Boudeville proposals in relation to growth poles and growth centres, the Porter industrial cluster model, the ESDP concept of polycentricity and the more recent place-based approach to territorial development.

Finally, the NPF should be regarded as more than simply an evolution from the NSS. It sets out starkly the unsustainability of trends established over recent decades and emphasises that the 'business as usual' approach is no longer a viable option. In that regard, there are echoes of the landmark paper by T. K. Whitaker in the late 1950s which became a catalyst for the economic transformation that began in the 1960s. One may hope that the NPF will have the same impact in bringing about the radical changes that are required for a new epoch between now and 2040; however, much will depend on the capacity to develop leadership structures that will promote and implement new pathways that can cater for diversity and involve partnerships between the public, private and voluntary civic sectors to achieve the ten strategic outcomes in the NPF for the benefit of society, the economy and the environment in the cities, towns and rural areas.

\section{Acknowledgements}

The author is very appreciative of the comments provided by the two referees on an earlier draft of this paper.

\section{References}

Albrechts, L. (2001). From traditional land use planning to strategic spatial planning. In L. Albrechts, J. Alden \& A. da Rosa Pires (Eds), The changing institutional landscape of planning (pp. 83-108). Aldershot: Ashgate.

Albrechts, L., Balducci, A., \& Hillier, J. (Eds) (2017). Situated practices of strategic planning: An international perspective. Routledge: London.

Allmendinger, P. (2009). Planning theory (2nd edn). Hampshire: Palgrave Macmillan.

Bannon, M. J. (1983) Urbanisation in Ireland: Growth and regulation. In J. Blackwell \& F. J. Convery (Eds), Promise and performance: Irish environmental policies analysed (pp. 261-86). Dublin: UCD. 
Bannon, M. J. (1989). Planning: The Irish experience 1920-1988. Dublin: Wolfhound Press.

Barca, F. (2009) An agenda for a reformed cohesion policy: A place-based approach to meeting European Union challenges and expectations. Brussels: European Commission.

Barca, F., McCann, P., \& Rodriguez-Pose, A. (2012). The case for regional development intervention: Place-based versus place-neutral approaches. Journal of Regional Science, 52 (1), 134-52.

Bartley, B. (2007). Planning in Ireland. In B. Bartley \& R. Kitchin (Eds), Understanding contemporary Ireland (pp. 31-43). London: Pluto Press.

Beer, A., Ayres, S., Clower, T., Faller, F., Sancino, A., \& Sotarauta., M. (2019). Place leadership and regional economic development: A framework for cross-regional analysis. Regional Studies, 53 (2), 171-82 .

Breathnach, P. (1982). The demise of growth centre policy: The case of the Republic of Ireland. In R. Hudson \& J. R. Lewis (Eds), Regional planning in Europe (pp. 35-56). London: Pion.

Breathnach, P. (2013). Regional governance and regional development: Implications of the action programme for effective local government. Administration, 61 (3), 51-73.

Central Statistics Office. (2019). Regional population projections 2017-2036. Dublin: Central Statistics Office.

Commission of the European Communities. (1999). European spatial development perspective: Towards balanced and sustainable development of the territory of the European Union. Luxembourg: Commission of the European Communities.

Committee on the Price of Building Land. (1973). Report of the Committee on the Price of Building Land. Dublin: The Stationery Office.

Consultative Council on General Hospital Services. (1968). Outline of the future hospital system. Dublin: The Stationery Office.

Davoudi, S. (2012). The legacy of positivism and the emergence of interpretive tradition in spatial planning. Regional Studies, 44 (4), 429-41.

Davoudi, S. D., \& Strange, I. (Eds) (2009). Conceptions of space and place in strategic spatial planning. London: Routledge.

Department of Housing, Planning and Local Government. (2017a). Ireland 2040 strategic environmental assessment report for the draft National Planning Framework. Dublin: Department of Housing, Planning and Local Government.

Department of Housing, Planning and Local Government. (2017b). Ireland 2040 strategic flood risk assessment report for the draft National Planning Framework. Dublin: Department of Housing, Planning and Local Government.

Department of Housing, Planning and Local Government. (2017c). Ireland natura impact statement for the draft National Planning Framework. Dublin: Department of Housing, Planning and Local Government. 
Department of Housing, Planning and Local Government. (2018). Implementation roadmap for the National Planning Framework. Dublin: Department of Housing, Planning and Local Government.

Faludi, A. (2000). The performance of spatial planning. Planning Practice and Research, 15 (4), 299-318.

Faludi, A. (2003). Planning theory. Oxford: Pergamon Press.

Faludi, A., \& Waterhout, B. (2002). The making of the European Spatial development perspective. London: Routledge.

FitzGerald, G. (1964). The role of development centres in the Irish economy. Administration, 12, 171-80.

Fitzgerald, J., Kearney, I., Morgenroth, E., \& Smyth, D. (1999) National investment priorities for the period 2000-2006 [ESRI policy research series no. 33]. Dublin: ESRI.

Gibney, F. (1943a). Framework for an Irish national plan. Dublin: Educational Company.

Gibney, F. (1943b). Suirbhéaracht Éireann [An Irish national survey]. Unpublished copy available in Planning library, University College Dublin, Ireland.

Gillmor, D. A. (1985) Economic activities in the Republic of Ireland: A geographical perspective. Dublin: Gill and Macmillan.

Government of Ireland. (1997). Sustainable development - A strategy for Ireland. Dublin: The Stationery Office.

Government of Ireland. (2002). National Spatial Strategy 2002-2020: People, places and potential. Dublin: The Stationery Office.

Government of Ireland. (2012). Putting people first: Action programme for effective local government. Dublin: Government Publications Office.

Government of Ireland. (2017). Ireland 2040 our plan: Draft National Planning Framework. Dublin: The Stationery Office.

Government of Ireland. (2018). Project Ireland 2040: National Planning Framework. Dublin: The Stationery Office.

Haughton, G., Allmendinger, P., Counsell, D., \& Vigar, G. (2010). The new spatial planning. London: Routledge.

Healey, P. (1998). Building institutional capacity through collaborative approaches to urban planning. Environment and Planning A, 30 (9), 1531-46.

Healey, P. (2006). Collaborative planning: Shaping places in fragmented societies. Hampshire: Palgrave Macmillan.

Hogan, P. (2018). Delivering on the National Planning Framework. Journal of the Statistical and Social Inquiry Society of Ireland, XLVII, 112-21.

MacCabe, F. (2018). The civic visions of Frank Gibney. Dublin: Castles in the Air Publications.

MacLaran, A., \& Kelly, S. (Eds) (2014). Neoliberal urban policy and the transformation of the city: Reshaping Dublin. Basingstoke: Palgrave Macmillan. 
McCafferty, D. (2007). Urban systems. In B. Bartley \& R. Kitchin (Eds), Understanding contemporary Ireland (pp. 57-70). London: Pluto Press.

McCafferty, D., Van Egaraat, C., Gleeson, J., \& Bartley, B. (2013). Urban specialisation, complementarity and spatial development strategies on the island of Ireland. Administration, 60 (3), 115-40.

Morgenroth, E. (2013). Economics - The missing link in the National Spatial Strategy. Administration, 60 (3) 41-60.

Moseley, M. (1974). Growth centres in spatial planning. Oxford: Pergamon Press.

NESC. (1975). Regional policy in Ireland: A review. Dublin: NESC.

NESC. (1982). A review of industrial policy. Dublin: NESC.

NESC. (1999). Opportunities, challenges and capacities for change. Dublin: NESC.

Newman, J. (1958). The future of rural Ireland. Studies, 47, 388-409.

Newman, J. (1967). New dimensions in regional planning: A case study of Ireland. Dublin: An Foras Forbartha.

OECD. (1965). Investment in education. Report for Ireland. Paris: OECD.

O'Farrell, P. N. (1971). The regional problem in Ireland: Some reflections upon development strategy. Economic and Social Review, 2, 453-80.

O'Farrell, P. N. (1974). Regional planning in Ireland - The case for concentration: A reappraisal. Economic and Social Review, 5, 499-514.

O'Leary, E. (Ed.) (2003). Irish regional development: A new agenda. Dublin: The Liffey Press.

O'Leary, S. (2014). Sense of place: $A$ history of Irish planning. Dublin: The History Press Ireland.

O'Neill, H. (1971). Spatial planning in the small open economy: A case study of Ireland. New York: Praeger.

O'Riordain, S. (2013). Governance and the National Spatial Strategy: Placing spatial policy at the heart of the diagonal public service. Administration, 60 (3), 141-58.

Pringle, D. (1989) Partition, politics and social conflict. In R. W. G Carter \& A. J. Parker (Eds), Ireland: Contemporary perspectives on a land and its people (pp. 23-54). London: Routledge.

Tribunal of Inquiry into Certain Planning Matters and Payments. (2012). Report of the Tribunal of Inquiry into Certain Planning Matters and Payments. Dublin: Government Publications.

Van Egaraat, C., Breathnach, P., \& Curran, D. (2013). Gateways, hubs and regional specialisation in the National Spatial Strategy. Administration, 60 (3), 91-114.

Walsh, C. (2019). Integration of expertise or collaborative practice? Coastal management and adaptation at the Wadden Sea. Ocean and Coastal Management, 167, 78-86.

Walsh, F. (1976). The growth centre concept in Irish regional policy. Maynooth Review, 2, 22-41. 
Walsh, J. A. (1989). Regional development strategies. In R. W. G. Carter \& A. J. Parker (Eds), Ireland: Contemporary perspectives on a land and its people (pp. 441-71). London: Routledge.

Walsh, J. A. (1993). Regional development in Ireland under the community support framework: Review and prospects. In H. Van der Kamp (Ed.), EC funds for Ireland: Getting it right (pp. 55-74). Dublin: Regional Studies Association (Irish Branch).

Walsh, J. A. (1995). Regions in Ireland - A statistical profile. Dublin: Regional Studies Association (Irish Branch).

Walsh, J. A. (2005). Spatial planning frameworks for Ireland: Critical reflections on the Dublin-Belfast corridor. In M. McEldowney, M. Murray, B. Murtagh \& K. Sterrett (Eds), Planning in Ireland and beyond (pp. 125-38). Belfast: Queen's University Belfast.

Walsh, J. A. (Ed.) (2007). People and place: A census atlas of the Republic of Ireland. Maynooth: NIRSA, Maynooth University.

Walsh, J. A. (2009). Space and place in the National Spatial Strategy in the Republic of Ireland. In S. Davoudi \& I. Strange (Eds), Conceptions of space and place in strategic spatial planning (pp. 95-124). London: Routledge.

Walsh, J. A. (2013). The National Spatial Strategy: Rationale, process, performance and prospects. Administration, 60 (3), 13-40. 